\title{
Kirjoittajat / Contributors
}

\section{OTSO HARJU}

otso.harju@helsinki.fi

Orcid ID https://orcid.org/0000-0002-3686-1027

Otso Harju on sukupuolentutkimuksen jatko-opis-

kelija Helsingin yliopistolla. Hänen väitöskirjansa käsittelee etnografian kautta feministisiä näkökulmia vanhempien tukeen ja valtaan Delhissa, Intiassa. Harju on elänyt viime vuosikymmenen Intian, Suomen ja Ruotsin välillä. Häntä kiinnostavat varsinkin transnationaaliset feminismit, yhteistyön mahdollisuudet ja kysymykset siitä, mitä yliopistomaailman epäoikeudenmukaisuuksille pitäisi tehdä.

\section{OTSO HARJU}

otso.harju@helsinki.fi

Orcid ID https://orcid.org/0000-0002-3686-1027 Otso Harju is a $\mathrm{PhD}$ candidate in gender studies at University of Helsinki, Finland. They are currently working on an ethnographic thesis on young feminist engagements with parental care-as-control in Delhi, India. For the past ten years, Harju has lived between India, Finland, and Sweden, and is particularly interested in questions of transnational feminisms, collaboration, as well as what to do about all the inequality in the academia.

\section{HARTO HÄNNINEN}

hannisenharto@gmail.com

Harto Hänninen, FM, on populaarikulttuurin ilmenemismuotoihin erikoistunut tietokirjailija ja toimittaja. Hänen tuorein radiosarjansa Iskelmän maantiede (2021) käsittelee toiseutta, rasismia ja kolonialismia suomalaisessa iskelmälyriikassa. Parhaillaan hän kirjoittaa tietokirjaa samasta aiheesta.

\section{HARTO HÄNNINEN}

hannisenharto@gmail.com

Harto Hänninen, MA, specializes in different forms of popular culture as a journalist and a non-fiction writer. His latest radio series Iskelmien maantiede [Geography of the song lyrics] (2021) deals with otherness, racism, and colonialism in Finnish popular song and schlager lyrics. He is currently writing a book on the same subject.

\section{TUULI INNOLA}

tuuli.innola@tuni.fi

Tuuli Innola on sukupuolentutkimuksen väitöskirjatutkija Tampereen yliopistossa ja hänen väitöstutkimuksensa käsittelee parisuhteiden ulkopuolella muotoutuvia tärkeäksi koettuja kumppanuuksia. Innola tarkastelee elämän jakamisen ja kumppanuuden rakentumista arkisissa sosiaalisissa ja materiaalisissa käytännöissä ja tunteissa, erityisesti affektiteorioita ja posthumanistisia teorioita hyödyntäen. Innola on kiinnostunut heteronormatiivisuuteen, parisuhdenormatiivisuuteen ja elämänkulun normeihin liittyvistä kysymyksistä sekä kokemusten ja affektien tutkimisesta. Hänen tutkimuksensa pyrkii haastamaan myös läheissuhdetutkimuksen ihmiskeskeisyyttä.

\section{TUULI INNOLA}

tuuli.innola@tuni.fi

Tuuli Innola is a second-year PhD Student in Gender Studies at Tampere University, Finland. Her study focuses on those significant and life-defining companionships that do not fit into categories of romantic and sexual couple relationships. Innola's study draws from affect theories and post-human thinking, as she analyses the experiences of relating and the processes of co-becoming that build the companionships. Innola is interested in issues around heteronormativity, couple-normativity, and life-course, as well as in challenging the humancenteredness of studies on intimacy and care.

\section{JARMO HARRI JANTUNEN}

jarmo.jantunen@jyu.fi

Jarmo Harri Jantunen on Jyväskylän yliopiston suomen kielen professori. Hän on julkaissut artikkeleja, sanakirjoja ja toimitettuja teoksia korpustutkimuksen alalta laajasti. Hänen tutkimuksensa koostuu korpuslingvistiikasta, korpusleksikografiasta, korpusonomastiikasta, fraseologiatutkimuksesta ja korpusavusteisesta diskurssintutkimuksesta. Hän on keskittynyt mm. korpusten koostamiseen (Kansainvälinen oppijansuomen korpus, ILCFI), annotointiin ja korpusmenetelmiin tarkastellessaan sekä kääntämisen tuloksena syntynyttä että kielenoppijoiden tuottamaa suomen kieltä. Viimeaikainen tutkimus on kohdistunut erityisesti queer-lingvistiikan alalla
103

Kirjoittajat Contributor 
lhbtq+-henkilöihin liittyviin diskursseihin ja sekä pääkaupunkiseutuun että lhbtq+-henkilöihin liittyvään segregaatioon.

\section{JARMO HARRI JANTUNEN}

jarmo.jantunen@jyu.fi

Jarmo Harri Jantunen is a professor of Finnish language at the University of Jyväskylä, Finland. He has published articles, book chapters, dictionaries, and edited volumes and books on corpus linguistics, corpuslexicography, corpus-onomastics, phraseology, and corpus-assisted discourse studies. The topics vary from the use of corpus compilation, annotation and methodology to the study of phraseology, translated Finnish, learner Finnish and language learning, and recently discourses related to $\mathrm{hbtq}+$ people. He was the PI in the International Corpus of Learner Finnish project. Currently he is conducting research in queer linguistics and on segregation among $\mathrm{lhbtq}+$ people and in the capital area of Finland.

\section{TUULA JUVONEN}

tuula.juvonen@tuni.fi

Dosentti, YTT Tuula Juvonen työskentelee sukupuolentutkimuksen yliopistonlehtorina Tampereen yliopistossa. Hänen aiemmat tutkimuksensa ovat käsitelleet lesbo- ja homoyhteisöjen syntyä, homoseksuaalisuuden muuttuvaa asemaa suomalaisessa yhteiskunnassa ja ajassa muuttuvia sukupuoli- ja seksuaalisuuskäsityksiä. Hän on julkaissut perustutkimusta suomalaisen homoseksuaalisuuden historiasta ja toimittanut Sateenkaarihistorian hakusanakirjan. Parhaillaan hän vetää Suomen Akatemian rahoittamaa tutkimushanketta Affektiivinen aktivismi: queerja transmaailmojen luomisen paikat (2021-2025). Hän on ollut myös perustamassa Sateenkaarihistorian ystävät ry:tä ja toimii tällä hetkellä yhdistyksen puheenjohtajana.

\section{TUULA JUVONEN}

tuula.juvonen@tuni.fi

Tuula Juvonen, DSocSci, works as a senior lecturer of Gender Studies at Tampere University. Her previous studies have focused on emerging lesbian and gay communities, the changing position of homosexuality in Finnish society, and the sexualities and genders in flux. She has published groundbreaking monographs about Finnish LGBT history and compiled an online Dictionary of Queer History. Currently she leads an Academy of Finland funded research project Affective Activism: Sites of Queer and Trans World-Making (2021-2025). Moreover, she is a cofounder and the chair of the registered association Friends of Queer History.

\section{JUKKA LEHTONEN}

jukka.p.lehtonen@helsinki.fi

Jukka Lehtonen on vanhempi tutkija sukupuolentutkimuksen oppiaineessa Helsingin yliopistossa. Hän on kasvatussosiologian dosentti, joka on keskittynyt tutkimuksessaan sukupuolen ja seksuaalisuuden moninaisuuteen sekä niiden risteäviin eroihin koulutuksessa ja työelämässä. Hän tekee tällä hetkellä tutkimusta koronakriisin vaikutuksista sateenkaari-ihmisiin ja -järjestöihin Suomen Akatemian Strategisen tutkimusneuvoston rahoittamassa CoWeAll-hankkeessa.

\section{JUKKA LEHTONEN}

jukka.p.lehtonen@helsinki.fi

Jukka Lehtonen is Senior Researcher in Gender Studies in the University of Helsinki. He has a title of docent in Sociology of Education. His research focus is on gender and sexuality diversity and their intersections with various differences in education and in work environments. His current research focuses on the experiences of covid-19 crises of lhbtq + people and human rights organisations. This CoWeAll research project is funded by the Academy of Finland Strategic Research Council.

\section{LEENA-MAIJA ROSSI}

leena-maija.rossi@helsinki.fi

Leena-Maija Rossi, FT, dos., toimii taidehistorian yliopistonlehtorina Helsingin yliopistossa. Rossin tutkimusintresseihin kuuluvat mm. intersektionaalisuus, queer-teoria ja -aktivismi, ja kriittinen valkoisuuden tutkimus. Hän on analysoinut visuaalisen kulttuurin eri muotoja mainonnasta ja elokuvasta televisio-ohjelmiin ja nykytaiteeseen. Hänen kirjoittamistaan ja toimittamistaan kirjoista viimeisin on Sanna Karkulehdon kanssa toimitettu Sukupuoli ja väkivalta: Lukemisen etiikkaa ja politiikkaa (SKS 2017) ja artikkeleistaan "Kuvassa kumppanilajin kanssa: Kissuus, queeriys ja samansuuntaiset katseet" (teoksessa Hanna Johansson \& Anita Seppä (toim.) Taiteen kanssa maailman äärellä. Taideyliopisto \& PARVS, 2021.)

\section{LEENA-MAIJA ROSSI}

leena-maija.rossi@helsinki.fi

Leena-Maija Rossi, $\mathrm{PhD}$, is a feminist researcher of visual culture based in Helsinki, Finland. Currently she teaches art history as Senior Lecturer at the University of Helsinki. Her research interests include politics of intersectionality, queer theory and activism, and critical studies of whiteness, as well as different forms of visual culture from advertising, film and television to contemporary art. She has published extensively, both in Finland and internationally, her latest book being Gender and Violence: Ethics and Politics of Reading (in Finnish, co-edited with Sanna Karkulehto, 2017), and latest article "In the Picture with Companion Species: Cathood, Queerness, and Parallel Gazes" (in Hanna 
Johansson \& Anita Seppä (eds.) Together with Art at the Edge of the World. University of the Arts, Helsinki \& PARVS, 2021.)

\section{TIIA SUDENKAARNE}

tiia.sudenkaarne@helsinki.fi

tiia.sudenkaarne@tuni.fi

Tiia Sudenkaarne VTT, FM on Helsingin yliopiston tutkijatohtori Suomen Akatemian projektissa Social Study of Microbial Resistance: Healthcare, Animals, and Ethics (32422) ja Tampereen yliopiston apurahatutkija Koneen Säätiön projektissa Technology, Ethics and Reproduction: Controversy in the Era of Normalisation (321711). Hän väitteli tohtoriksi syyskuussa 2021 Turun yliopiston filosofian oppiaineesta. Hänen väitöstutkimuksensa käsitteli feminististä bioetiikkaa ja queer-bioetiikkaa. Sudenkaarne pohtii parhaillaan queer-feministisiä, posthumanistisia tulokulmia antibioottiresistenssin etiikkaan.

\section{TIIA SUDENKAARNE}

tiia.sudenkaarne@helsinki.fi

tiia.sudenkaarne@tuni.fi

Tiia Sudenkaarne DrSocSci, MA is a postdoctoral researcher at University of Helsinki in the project Social Study of Microbial Resistance: Healthcare, Animals, and Ethics (32422) funded by Academy of Finland and a grant researcher at University of Tampere in the Technology, Ethics and Reproduction Controversy in the Era of Normalisation (321711) project funded by Kone Foundation. She received her doctorate in philosohy from University of Turku in September 2021, with a dissertation on feminist and queer bioethics. Sudenkaarne is currently thinking about queer feminist, posthumanist angles to ethics of antimicrobial resistance.

\section{JOONAS SÄNTTI}

joonas.s.santti@jyu.fi

FM Joonas Säntti on väitöskirjatutkija Jyväskylän yliopistossa. Hänen tutkimusjulkaisunsa käsittelevät erityisesti nykykirjallisuuden sukupuolettomia kertojia. Queer-narratologinen tutkimus lähestyy queeria tekstuaalisena ilmiönä: kerrontaratkaisut hankaloittavat äänten ja henkilöiden paikantamista ja nimeämistä. Säntti on työskennellyt myös kirjallisuuskriitikkona, esseistinä ja yliopistonopettajana.

\section{JOONAS SÄNTTI}

joonas.s.santti@jyu.fi

Joonas Säntti, MA, is a doctoral candidate in the University of Jyväskylä. Their research publications focus on ungendered narrators in contemporary prose fiction. Their queer narratological approach attends to textual queer: how the narrative elements complicate the situating and naming of voices and characters. They have also worked as a literary critic, essayist and university teacher.

\section{RIIKKA TAAVETTI}

riikka.taavetti@helsinki.fi

http://riikkataavetti.fi/

ORCID: 0000-0001-9601-2206

VTT, FM Riikka Taavetti työskentelee poliittisen historian yliopistonlehtorina Helsingin yliopistossa. Hänen aiemmat tutkimuksensa ovat käsitelleet queerhistoriaa sekä muistin politiikkaa ja muistitietoa Suomessa ja Virossa. Hän on tutkinut myös suomalaisen seksitutkimuksen tieteenhistoriaa. Tällä hetkellä Taavetti osallistuu Koneen Säätiön rahoittamaan Sexuality and democracy: Exploring the links and re-thinking the concepts for feminist politics (SEXDEM) -hankkeeseen, jossa hänen tutkimuksensa käsittelee homoseksuaalisuudesta käytävää poliittista keskustelua Virossa ja Ruotsissa.

\section{RIIKKA TAAVETTI}

riikka.taavetti@helsinki.fi

http://riikkataavetti.fi/

ORCID: 0000-0001-9601-2206

Riikka Taavetti, PhD, works currently as a University Lecturer in political history at the University of Helsinki. Her research has addressed Estonian and Finnish queer history, politics of memory, and oral history. She has also studied the intellectual history of Finnish sex research. Her current work analyzes the political discussions on homosexuality in Estonia and Sweden and is a part of the research project Sexuality and democracy: Exploring the links and re-thinking the concepts for feminist politics (SEXDEM), funded by the Kone Foundation.

\section{JIIPU UUSITALO}

https://tajukankaankutoja.sarjakuvablogit.com/ Sarjakuvapiirtäjä Jiipu Uusitalo elää ja työskentelee Tampereella. Hän on julkaissut 2000-luvun alusta saakka surrealismia ja infosarjakuvaa yhdisteleviä töitään sarjakuvablogissaan ja pienissä omakustannelehdissä. Viime vuosina Uusitalo on piirtänyt pidempiä sarjakuva-albumeja, joiden julkaisijana on toiminut Täysi Käsi Oy. Hänen pääteoksensa tähän asti on valta-trilogia, jonka osat ovat Kukkaisruoska (2019), Puupenni (2020) ja Okanaamio (2021). Tällä hetkellä Uusitalo piirtää kaupunkiviljelystä kertovaa Itämisen ihme -albumia.

\section{JIIPU UUSITALO}

https://tajukankaankutoja.sarjakuvablogit.com/

The comic artist Jiipu Uusitalo lives and works in Tampere. Since the beginning of the 2000s, they have published work that combines surrealism and info comics, both as blog posts in their "Tajukankaankutoja" and in self-published zines. In recent years, Uusitalo has drawn extended 
graphic novels, published by Täysi Käsi Oy. Their major achievement to date is a trilogy on power, comprising the albums Kukkaisruoska [The Flower Whip] (2019), Puupenni [The Wooden Penny] (2020) and Okanaamio [The Thorn Mask] (2021). Currently, Uusitalo is working on an album entitled Itämisen ihme [The Wonders of Sprouting] about city gardening.

\section{LOIS-ANNE WATT}

lois.watt@helsinki.f

lois.annewatt@gmail.com

Lois-Anne Watt - ihmismaantieteiden maisteri Aberdeenin yliopistosta - opiskelee tällä hetkellä Helsingin yliopiston maisteriohjelmassa nyky-yhteiskuntien sosiaali- ja kulttuuriantropologiaa. Paraikaa hän valmistelee tutkielmaansa, joka käsittelee sitä, kuinka avovesissä uimisen käytännöt kietoutuvat identiteetin ja tilallisuuden saamiin merkityksiin Koillis-Skotlannissa. Tutkimuksessa huomio kiinnitetään erityisesti ruumiilliseen vuorovaikutukseen sukupuolen muotoutumisessa ja ihmisyyden rajat ylittävissä kohtaamisissa. Hänen aiempiin tutkimushankkeisiinsa lukeutuu historiallinen analyysi sukupuoliroolien muutoksesta ja kuulumisen tunteesta skotlantilaisen maaseudun kalastajayhteisöissä 1900-luvulla.

\section{LOIS-ANNE WATT}

lois.watt@helsinki.f

lois.annewatt@gmail.com

Lois-Anne Watt - Scottish MA (Hons) in human geography at the University of Aberdeen - is currently studying social and cultural anthropology in the contemporary societies (MA) programme at the University of Helsinki. At the moment, she is drafting a thesis concerning the practice of open water swimming (otherwise known as, 'wild swimming') in the North-East of Scotland, and is investigating how the development of such practices are embedded within notions of identity and place-making. This research holds a specific interest with formations of gender and more-than human encounters through bodily interactions. Her past research projects include a historic analysis of changing gender roles and notions of belonging within rural fishing communities in Scotland over the last century. 